AperTO - Archivio Istituzionale Open Access dell'Università di Torino

Women's Participation in Voluntary Associations in Italy.

This is a pre print version of the following article:

Original Citation:

Availability:

This version is available http://hdl.handle.net/2318/154356

since

Publisher:

Springer

Published version:

DOI:10.1007/978-94-007-0753-5_4210

Terms of use:

Open Access

Anyone can freely access the full text of works made available as "Open Access". Works made available under a Creative Commons license can be used according to the terms and conditions of said license. Use of all other works requires consent of the right holder (author or publisher) if not exempted from copyright protection by the applicable law. 
This is the author's final version of the contribution published as:

D. Acquadro Maran. Women's Participation in Voluntary Associations in Italy.. Springer. 2014. pp: 7163-7166.

in

\section{Encyclopedia of Quality of Life Research}

The publisher's version is available at:

http://link.springer.com/content/pdf/10.1007/978-94-007-0753-5_4210

When citing, please refer to the published version.

Link to this full text:

http://hdl.handle.net/2318/154356 


\section{Metadata of the chapter that will be visualized online}

\begin{tabular}{|c|c|c|}
\hline Chapter Title & \multicolumn{2}{|c|}{ Women's Participation in Voluntary Associations in Italy } \\
\hline Copyright Year & \multicolumn{2}{|l|}{2013} \\
\hline Copyright Holder & \multicolumn{2}{|c|}{ Springer Science+Business Media Dordrecht } \\
\hline \multirow[t]{9}{*}{ Corresponding Author } & Family Name & Maran \\
\hline & Particle & \\
\hline & Given Name & Daniela Acquadro \\
\hline & Suffix & \\
\hline & Division/Department & Department of Psychology \\
\hline & Organization/University & Università degli studi di Torino \\
\hline & City & Torino \\
\hline & Country & Italy \\
\hline & Email & daniela.acquadro@unito.it \\
\hline
\end{tabular}




\section{Women's Participation in Voluntary Associations in Italy}

\author{
Daniela Acquadro Maran \\ Department of Psychology, Università degli studi \\ di Torino, Torino, Italy
}

\section{Definition}

Voluntary associations could be laboratories for testing different organizational forms, in which women could have (a) a greater chance (than in for-profit organizations) of participating actively in the association and (b) more access to managerial and leadership roles. For this goal, volunteers need organizational rules and norms oriented toward encouraging them to participate in all organizational roles.

\section{Description}

\section{Introduction}

- Volunteerism is an extremely fascinating context for social science scholars: lacking the economic variable of the relationship within the working group, it is possible to investigate the phenomena of teamwork without the bonds that generally characterize for-profit organizations (Milligan \& Fyfe, 2005). Women's participation is among the topics investigated (Einolf, 2011). According to studies conducted in Italy, the number of women engaged in volunteerism has increased year by year, and women currently 29 account for $50.8 \%$ of the entire national volun- 30 teer population. A third of these women have 31 $>$ leadership roles, and in $70 \%$ of all cases, 32 such roles are performed in associations with 33 a predominantly female membership (i.e., at 34 least $60 \%$ ). Of all the $>$ voluntary associations 35 in Italy, $30.2 \%$ are made up largely or entirely of 36 women, while $40.5 \%$ have an all-male member- 37 ship. Of those with male and female members, 38 $37.7 \%$ women account for between $0 \%$ and $33 \% 39$ of all members, while $32.2 \%$ have a female 40 membership of between $34 \%$ and $66 \%$. As for 41 the characteristics of women who provide volun- 42 teer services in largely female associations, 43 $56.3 \%$ are over 45 years of age (in the predom- 44 inantly male voluntary associations, the percent- 45 age for this age group is less than half), and $63 \% 46$ are women who turn to voluntary activities at the 47 end of their working life (i.e., after retirement) or 48 do not have a job (students, housewives) 49 (Frisanco, 2001; International Society of Trans- 50 port Aircraft Trading [ISTAT], 2005). As shown 51 in previous research (see Pearce, 1993), volun- 52 tary associations also attract volunteers because 53 of their different organizational approach (in 54 terms of rules and patterns) compared to for- 55 profit groups. Men and women who are members 56 of voluntary associations may have an opportu- 57 nity to acquire new skills (e.g., to study history 58 and art to accompany tourists visiting a museum) 59 or to put some particular competence into prac- 60 tice that they would otherwise have no particular 61 use for (e.g., teaching disadvantaged young 62 
people to play the guitar) or that is of no particular relevance in ordinary life (e.g., driving a car to accompany patients), In this particular context, do women have a greater chance (than in forprofit organizations) of participating actively in the association, do they have more access to managerial and leadership roles?

\section{Method}

In order to answer these questions, an investigation was conducted involving 91 volunteers. They belong to different types of associations: organizations engaged in social work, support for cooperation and development projects, cultural promotion, emergency services, environmental protection, safeguarding human and civil rights, and health care (13 volunteers from each association). Women accounted for $57.2 \%$ of the participants, whose age ranged from 16 to 73 (median, 45 years). They answered questions such as how are dates and times defined for group activities (e.g., meetings) and individual activities (e.g., shifts in the soup kitchen), when and how are decisions made, and what characteristics are required to become a manager or leader. - Content analysis methodology (Ghiglione, 1980) was used to analyze the text material collected; the statistical program Alceste 4.6 (Analyze de Lexèmes Cooccurrents dans les Enoncés Simples d'un Texte - by Reinert, 1987) was also used to obtain the most frequently used words and the internal organization of the discourse.

\section{Result}

The data gathered indicate that volunteers (women and men) need organizational rules and > norms oriented toward encouraging them to participate in all organizational roles, including leadership and management roles. If voluntary associations do not adopt flexible rules and settings, they risk failure: voluntary associations need to create an atmosphere that is more able to accommodate everybody's needs. Participants reported that managerial and leadership roles are assigned both on the basis of men's and women's views about who should assume such roles and on the type of work that the voluntary association does. Many women (generally aged $>55$ years) actually prefer men to hold certain roles that they 109 associate more with males, such as money man- 110 agement or group leadership. Voluntary associa- 111 tions could have an important function in 112 changing this type of mentality, by giving 113 women (of all ages) a chance to try their hand at 114 these roles. As for the type of work engaged in by 115 the voluntary association, as Eagly's work has 116 shown (Eagly \& Carli, 2007), leadership is - at 117 least in Italy - still linked to expectations regard- 118 ing $>$ gender roles. Voluntary associations are 119 not exempt from the social and cultural processes 120 at work elsewhere. The data from this investiga- 121 tion indicate that women are more likely to be 122 chosen as leaders in women's volunteer groups, 123 where their behavior more closely reflects gender 124 stereotypes and the association's values and 125 norms (see Eagly, Makhijani, \& Klonsky, 126 1992). Data gathered during the interviews con- 127 firm this rule: an increase in the number of men in 128 an association could disrupt the group's equilib- 129 rium. That equilibrium can be restored by 130 redistributing assignments, but new assignments 131 could penalize women's leadership and manage- 132 rial roles in order to preserve the stereotype that 133 fosters their participation and inclusion (Martin, 134 2003). From the literature and data gathered, it 135 emerges that an association's norms and values 136 are the crucial elements that determine which of 137 the volunteer group members are singled out for 138 roles as leaders and managers. The leader in 139 particular is required to guarantee and preside 140 over not only the association's mission but also 141 its vision, so that its specific character can be 142 perpetuated. The vision is perpetuated through 143 recognition for work done. In particular, ceremo- 144 nies contain rites and rituals that reinforce the 145 type of conduct for which volunteers are symbol- 146 ically rewarded (e.g., with medals). The goal is to 147 build a sense of belonging to the group, and this is 148 essential for volunteers because it strengthens the 149 processes of inclusion and participation (Farmer 150 \& Fedor, 2003), enabling members to express 151 themselves and feel welcome, accepted, to take 152 on responsibilities, to try their hand at new roles. 153 


\section{Discussion}

So, how is it possible to support women to enable them to express their potential within voluntary associations? The answer is to be found in the commitment of their members to remove obstacles to women's participation, to establish norms to welcome and integrate diversity, and to help balance the demands that a dual presence in the workplace and the domestic sphere can entail. Women of all ages (but also most of the men in our investigation) wanted voluntary associations to remove all barriers to participation, including problems involved in balancing an individual's many responsibilities (e.g., work or school and family).

Voluntary associations - like all for-profit and not-for-profit organizations - could benefit from greater diversity in gender (but also in age, knowledge, skills, ethnicity, and so on) first in their members and consequently in the people who occupy managerial and leadership roles. This could have a positive impact on life within the association and result, for example, in more time being dedicated to the decision-making process and more new ideas about how to acquire resources (fund-raising and/or recruiting more volunteers) (Hackman, 2002). Greater diversity among members could enable each volunteer to improve the ways in which they participate, not only in the activities of voluntary associations but also in for-profit organizations: if good relationships are established, this approach could be an example for all organizations to follow. Thus, voluntary associations are being asked to devote more attention to each individual's skills, desires, and capabilities and to bear in mind that all volunteers have the right to aspire to lead the life they can and want to lead (Singh, 2002). What could voluntary association leaders do? First, they need to reflect on the association's mission and vision, the effect of these on the association's norms and values, the type of $\checkmark$ decision-making processes adopted by the group, and the resulting efforts to provide support and closure. This reflection is also essential if the association is to survive. Volunteers - both men and women - describe the failure of the process of inclusion and participation as one of the factors that cause voluntary associations to fall apart. In 202 such cases, change must necessarily come from 203 within the organization. Moreover, from the data 204 gathered, it emerged that voluntary associations 205 that do not adopt norms and values oriented 206 toward acceptance and involvement put their 207 own survival at risk: members could move to 208 another association or set up their own associa- 209 tion in which the rules and settings are more 210 oriented toward participation, flexibility, and 211 inclusiveness. This process is not possible in 212 for-profit organizations, whereas in voluntary 213 associations, people are not bound by formal 214 contracts but by emotional and affective ties and 215 by their own sense of responsibility, so they can 216 choose to leave the association and voluntary 217 activities, change the association from within 218 (e.g., by becoming a leader), or create one of 219 their own (alone or with other members of the 220 same association). Change could prove particu- 221 larly constructive for women: after gaining expe- 222 rience with one association, they could create 223 another more suited to their needs and explore 224 new roles. Essentially, if a voluntary association 225 is unable to meet the current needs of people (and 226 society), it is destined to fail. This process carries 227 the risk of fragmentation, a phenomenon that is 228 already present in the Italian context: in 2003, for 229 each organization that closed down, more than 10230 new ones were registered (ISTAT, 2005). New 231 organizations could adopt a different vision, 232 a strategy that fosters inclusion and participation 233 of women and young people, who are the future 234 of volunteer work. And this could create 235 a virtuous circle: if volunteering is satisfying, 236 the voluntary association is more likely to attract 237 new people who can contribute to fueling its 238 mission and vision (Mattsson \& Stenbacka, 239 2003): the data obtained indicate that one of the 240 major channels through which people access vol- 241 unteer work is that of friends and acquaintances 242 who promote the voluntary association on the 243 basis of their experience with it. Therefore, 244 a very important aspect that emerged from the 245 interviews is the birth of the association, the 246 moment when the founders declare its mission 247 and vision; the rules, norms, and values shared by 248 all members; and the ability of members to 249 
comply with these. Furthermore, when women set up a new association, they must have a role in proposing and stimulating change toward an organizational style and climate that is more in line with their needs and desires. This process could be difficult, as men and women who have experienced failure could repeat the same organizational mistake. In the interviews, some volunteers expressed the need to understand which organizational models are best suited to women and how these can be adapted to voluntary association contexts. Voluntary associations show considerable promise as laboratories for testing different organizational forms, as this investigation indicates that voluntary associations are potentially more easily adaptable to suit their member's needs.

\section{Cross-References}

- Participation in Civil Society

\section{References}

Eagly, A. H., \& Carli, L. L. (2007). Women and the labyrinth of leadership. Harvard Business Review, $85,76-85$.

Eagly, A. H., Makhijani, M. J., \& Klonsky, B. G. (1992). Gender and evaluation of leadership: A meta-analysis. Psychological Bulletin, 111, 3-22.
Einolf, C. (2011). Gender differences in the correlates of 276 volunteering and charitable giving. Nonprofit and Vol- 277 untary Sector Quarterly, 40(6), 1092-1112. 278

Farmer, S. M., \& Fedor, D. B. (2003). Volunteer partici- 279 pation and withdrawal. Nonprofit Management \& 280 Leadership, 9(4), 349-368.

Frisanco, R. (Ed.). (2001). Terza rilevazione fivol 2001282 sulle organizzazioni di volontariato. Roma: Settore 283 Studi e Ricerche Fondazione Italiana per il 284 Volontariato. 285

Ghiglione, R. (1980). Manuel d' analyse du contenu. Paris: 286 Colin.

Hackman, J. R. (2002). Leading teams. Setting the stage 288 for great performance. Boston: Harvard Business 289 School Press. 290

ISTAT. (2005). Le organizzazioni di volontariato in Ita- 291 lia. Roma: Istituto nazionale di statistica. 292

Martin, P. Y. (2003). "Said and done" versus "saying and 293 doing": gendering practices, practicing gender and 294 work. Gender and Society, 17, 342-366. 295

Mattsson, K.T., \& Stenbacka, S. (2003). Gendered Social 296 Capital: A case study of sports and music associations 297 in Leksand and Rattvik, Sweden. $43^{\text {rd }}$ Congress of the 298 European Regional Science Association, 21-31 August 299 2003, University of Jyväskylä, Finland. 300

Milligan, C., \& Fyfe, N. (2005). Making space for volun- 301 teers: Exploring the links between voluntary organiza- 302 tions, volunteering and citizenship. Journal of Urban 303 Studies, 42, 3 .

Pearce, J. L. (1993). Volunteers. London: Routledge. 305

Reinert, M. (1987). Un logiciel d'analyse lexicale: 306 ALCESTE. Cahiers de l'analyse des Données, 4, 307 471-484.

Singh, V. (2002). Managing diversity for strategic advan- 309 tage. A report for the council for excellence in man- 310 agement and leadership. London: Crowe. 311

Sirianni, C., \& Friedland, L. (2001). Civic innovation in 312 America: Community empowerment, public policy, 313 and the movement for civic renewal. Berkeley, CA: 314 University of California Press. 


\section{Author Query Form}

Encyclopedia of Quality of Life Research

Chapter No: 4210

\begin{tabular}{|l|l|l|}
\hline Query Refs. & Details Required & Author's response \\
\hline AU1 & Please cite Sirianni and Friedland (2001) in text. & \\
\hline
\end{tabular}

